\title{
MEMS-Based Microdevice for Cell Lysis and DNA Extraction
}

\author{
Xing Chen, Dafu Cui, Haoyuan Cai, \\ Hui Li, Jianhai Sun and Lulu Zhang \\ State Key Lab. of Transducer Tech., Inst. of Electronics, Chinese Academy of Sciences
}

China

\section{Introduction}

With the development of microelectromechanical system (MEMS) technology, micrototal analytical systems ( $\mathrm{TTAS}$ ) which has the potential for integrating sample pretreatment, target amplification, and detection, has been in progress. Micromachined analytical systems have several advantages over their large-scale counterparts, including low cost, disposability, low reagent and sample consumption, portability, and lower consumption. Many such devices have been demonstrated in the literature, including PCR microchips (Northrup et al., 1993; Copp et al., 1998; Panaro et al., 2005), DNA microchips (Fan et al., 1999), DNA biosensors (Kwakye et al., 2006), capillary electrophoresis (CE) microchips (Harrison et al., 1993; Backhouse et al., 2003; Liu et al., 2006), protein microchips (Yang et al., 2001; Wilson \& Nie, 2006), etc. Most of these analytical processes need an effective yet simple method of obtaining high-quality DNA. Hence miniature devices for rapid sample pretreatment of DNA, including cell lysis and genomic DNA purification, are crucial for genetic application.

Traditional phenol extraction is a complex and time-consuming method for extracting DNA, and even some commercial purification kits require several centrifugal operations. The implementation of DNA purification on a microdevice is initially demonstrated based on the principle of solid phase extraction (SPE). The SPE on-microdevice can minimize sample loss and contamination problems as well as reduce analysis time, and besides, this SPE method can avoid problems of physical and biochemical degradation of DNA. For example, Tian et al. (Tian et al., 2000) established an SPE DNA purification microdevice in a capillary packing with silica resin matrix which could extract enough DNA for PCR reaction. Wolfe et al. (Wolfe et al., 2002) and Breadmore et al. (Breadmore et al., 2003) immobilized bare-silica beads matrix in microchannels by sol-gel technology for DNA purification. But a high packing density for larger surface area in the microfluidic device results in problems of backpressure and clogging of crude samples, and what is more, it is difficult to control the small particles in microdevices. A micropillar array fabricated by MEMS technology in a microchamber or channel increases the surface area available for DNA adsorption (Christel et al., 1999; Cady et al., 2003). However, the increasing surface area is limited and the problems of clogging could not be completely solved. Hence, a novel solid-phase matrix which should be easily integrated in microdevices is under demand. 
It is well known that porous silicon with a relatively large specific surface area-to-volume (hundreds of square meters per cubic centimeter) can significantly increase the available interface area. Porous silicon can be easily obtained by electrochemical etching technology, and the pore geometry, the surface morphology, and the porosity of porous silicon can be very precisely controlled by the electrochemical etching conditions (Bisi et al., 2000; Schmuki et al., 2003). Porous silicon with several useful characteristics has already found applications in diverse fields such as solar cells (Bilyalov et al., 2003), RF (Park et al., 2001), (bio)chemical sensors (Massera et al., 2004; Björkqvist et al., 2004), etc.. Furthermore porous silicon with huge surface area as a kind of biocompatible solid support has been used to absorb enzyme, protein and other biologic molecules in fields of the enzyme micro reactors (Melander et al., 2005; Bengtsson et al., 2002), chromatography (Clicq et al., 2004), and antibody micro arrays (Steinhauer et al., 2005). Due to the fact that the technology for porous silicon fabrication is compatible with standard microelectronic and MEMS techniques, we have made use of porous silicon as the solid-phase matrix to extract DNA (Chen et al., 2006, 2007).

DNA purification from initial samples requires disrupting cells to liberate the nucleic acids before SPE process. Typical laboratory protocols for lysis steps include the use of enzymes (lysozyme), chemical lytic agents (detergents), and mechanical forces (sonication, bead milling). However, many such lysis techniques are not amenable to be implemented in a microfluidic platform. Miniaturization methods for lyzing cells are required so that cell lysis can be integrated into the $\mu$ TAS. Therefore, a desirable lysis method should rapidly destroy cells while at the same time, it could not destroy nucleic acids and inhibit the following PCR reaction either, which would be amenable to be integrated with SPE on microdevices. Carlo et al. (Carlo et al., 2003) reported a mechanical cell lysis microdevice with nanostructural barbs which was used to disrupt sheep blood cells. However, the fabrication process of nanostructures is complex. Other miniaturization cell lysis methods include thermal (Lee \& Tai, 1999), electrical (Gao et al., 2004; Taylor et al., 2001), ultrasonication (Belgrader et al., 2000; LaMontagne1 et al., 2002), and chemical treatments (Li \& Jed Harrison, 1997). These approaches have been shown to be moderately successful. However, they all depend on the use of an external power supply and the devices may be quite complicated and costly to fabricate. Hence, chemical disruption methods are chosen due to the fact that they can be compatible with SPE on microdevices and do not require complex process of fabrication either. For example, Schilling et al. (Schilling et al., 2002) reported a relatively simple T-type microfluidic device that allowed the continuous lysis of bacterial cells using $\beta$-galactosidase. Sethu et al. (Sethu et al., 2004) established a continuous-flow microfluidic device for rapid erythrocyte lysis.

In this chapter, we have described a novel integrated MEMS-based microdevice capable of performing online cell lysis and genomic DNA purification during continuous flowing process. The method of chemical disruption was chosen for cell lysis, while the method of solid phase extraction was chosen for DNA purification. For cell lysis microdevice based on chemical disruption method, mixing is the key step due to the fact that each cell should be fully exposed to lysis buffer before the total lysis of cells, which is limited by the mixing speed. The mixing procedure was numerically simulated. Based on the results of the simulation, the mixing model for cell lysis was optimized to construct the microfluidic devices fabricated by MEMS technology. For DNA purification microdevice based on the SPE principle, solid-phase matrix is the key factor. The porous silicon was used as the solidphase matrix to extract DNA. The porous silicon dioxide matrix was fabricated by 
electrochemical etching technology, and then were characterized by using SEM (scanning electron microscopy) and BET (Brunauer, Emmet, and Teller) nitrogen adsorption technique. The porous layer directly generated on the internal walls of the channels can greatly enhance the "active" surface area compared to the non-anodized one, and also avoid the problems of packing solid phase matrix.

In this integrated microdevice, cells were rapidly lyzed at first, and then genomic DNA was released and absorbed on a solid-phase matrix. Secondly, washing buffer was pumped through this microdevice for removing the proteins and other impurities which were also absorbed during the previous process. Finally, elution buffer was used to elute DNA and the desorbed DNA was collected at the outlet port. During continuous flow process, on-line rapid cell lysis and PCR amplifiable genomic DNA purification on the single MEMS-based microdevice have been implemented, which confirmed that the proposed microfluidic device was capable of directly providing genic analyte for the following molecular biology research or medical assay.

\section{Theory}

In microdevice channels, the flow is laminar in nature. Reynolds number, which is the ratio of the inertial forces to the viscous forces, can be used to characterize the flow. It is given by

$$
\operatorname{Re}=\rho \vee D_{h} / \mu
$$

Where $\rho$ is the fluid density, $\mathrm{v}$ is the flow velocity, and $\mu$ is the fluid viscosity. $\mathrm{D}_{\mathrm{h}}$ represents the hydraylic diameter and, for rectangular channels, is given by

$$
\mathrm{D}_{\mathrm{h}}=2 \mathrm{ab} /(\mathrm{a}+\mathrm{b})
$$

Where $\mathrm{a}$ and $\mathrm{b}$ are the cross sectional dimensions of the channel. The Reynolds numbers involved in the field of microfluidic device are usually below 100 (Gravesen et al., 1993), which prevent turbulent flow.

According the formula (1), the fluid density $(\rho)$ and the fluid viscosity $(\mu)$ are constants. Re is depended on the flow velocity $(\mathrm{v})$ and the hydraylic diameter $\left(\mathrm{D}_{\mathrm{h}}\right)$. For our microdevice with a $200 \mu \mathrm{m}$ wide and $100 \mu \mathrm{m}$ deep rectangle channel, the hydraylic diameter $\left(D_{h}\right)$ calculated by the formula (2) is $133 \mu \mathrm{m}$. Note that the blood density $(\rho)$ is $1.05 \mathrm{~g} / \mathrm{cm}^{3}$, and the viscosity of blood $(\mu)$ is $3.115 \mathrm{mPa}$.s. According to the formula (1), the Re in our experimental was $0.035 \sim 8.4$, when the flow velocity $(\mathrm{v})$ is about $0.0008 \sim 0.024 \mathrm{~m} / \mathrm{s}$. Therefore a typical laminar flow is found in our experimental. Lack of turbulent flow limits the effective mixing of the fluids under investigation. On the other hand, for the cell lysis on the microdevice based on the chemical method, it requires that each cell should be fully exposed to lysis reagents in microchannels, which is determined by mixing performance of the microdevice. In microdevice channels where flow is laminar in nature, the mixing is dictated by diffusion. Average time for a small portion of a fluid to diffuse a distance L can be estimated by

$$
\mathrm{T}_{\mathrm{D}}=\mathrm{L}^{2} / \mathrm{D}
$$

Where $\mathrm{D}$ is the diffusion coefficient of the liquid. The above equation can be used to predict the order of time scale of mass diffusion. As it suggests, one can dramatically reduce the mixing time by reducing the diffusion length required for mixing or increasing the contact area between two different liquids while keeping the volume constant. 


\section{Experimental}

\subsection{Reagents}

Triton- $\mathrm{X}$ 100, $\mathrm{HNO}_{3}, \mathrm{KOH}$, ethanol, Tris, EDTA, and $\mathrm{HCl}$ were purchased from Beijing Chemical Reagents Company (Beijing China). SYBR Green I dye was purchased from Molecular Probes (Leiden, The Netherlands). Guanidine thiocyanate, $\lambda$-DNA, nucleic acid extraction kit, and PCR kit were purchased from Tianwei (Beijing China). Primers for the 203-bp, -gapd gene and primers for the 250-bp, -action gene were purchased from Sangon (Shanghai China).

Diluted buffer $(0.9 \% \mathrm{NaCl}$ in PBS) was used to dilute whole blood. TE buffer (10mM Tris, 1 mM EDTA, titrated to $\mathrm{pH} 8$ ), load buffer (4M GuSCN in TE buffer with $1 \%$ Triton-X 100, titrated to $\mathrm{pH} 6.7)$, wash buffer $(70 \%$ ethanol with $10 \mathrm{mM} \mathrm{NaCl})$ and eluted buffer (namely TE buffer) were used for the DNA purification procedure. All solutions were prepared in distilled water.

\subsection{MEMS-based microdevice design and fabrication}

T-type mixing model and sandwich type mixing model were proposed. In the sandwich type model, line-type model and coil-type model of the mixing microchannels were designed. All the models (see Fig.2) were numerically simulated. The best model with the best mixing performance was used to construct the silicon substrate. The mixing condition of the best model was optimized by numerical simulation, and then it was verified by cell lysis experiments.

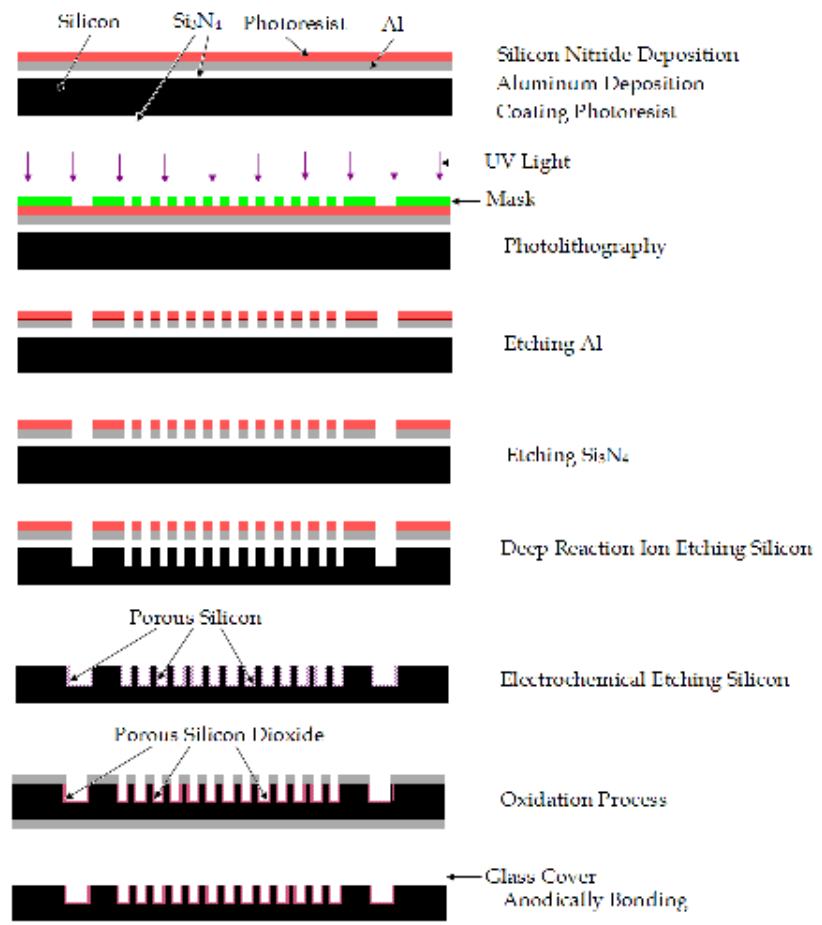

Fig. 1. Sequence for fabrication of the microdevice. 


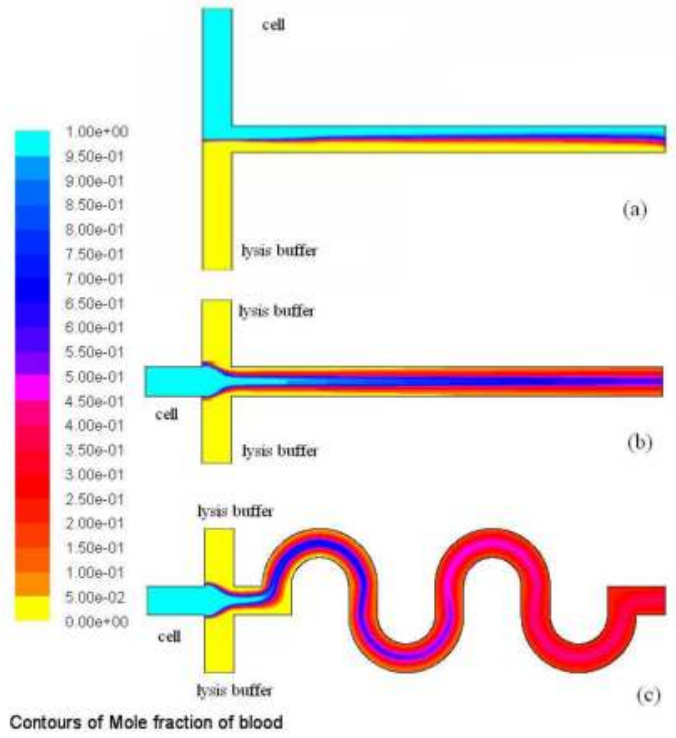

Fig. 2. Numerical simulation results for the species concentration distributions at T-type mixing model (a), sandwich type mixing model with lined channel (b) and sandwich type mixing model with coiled channel (c) when $v_{\text {cell }}=0.005 \mathrm{~m} / \mathrm{s}, \mathrm{v}_{\text {buffer }}=0.0025 \mathrm{~m} / \mathrm{s}$. The color for "1.00e+00" and " $0.00 \mathrm{e}+00$ " in this figure refers to the concentration intensity of the pure cell sample and the pure lysis buffer, respectively. The software of FLUENT 6.2 was used to simulate.

The microdevice consisted of a silicon substrate and a glass cover. The fabrication process was shown in Fig. 1. A double-side polished n-type 0.01-0.1 $\Omega \cdot \mathrm{cm}$ silicon wafer of (100) crystal orientation was first deposited with $0.3 \mu \mathrm{m}$ thick of silicon nitride $\left(\mathrm{Si}_{3} \mathrm{~N}_{4}\right)$ as the mask for fabricating porous silicon by a chemical vapour deposition (CVD) method, and then with $0.3 \mu \mathrm{m}$ aluminum as the mask for deep reaction ion etching (DRIE) by a electron beam vapour deposition technology. The wafer was spin coated with a positive photoresist (AZ1500) and patterned. After the exposed photoresist was developed, the exposed aluminum was removed by phosphoric acid and then the exposed silicon nitride was removed by plasma etching. The wafer was etched in a deep reaction ion etcher (Adixen, AMS100) to produce rectangle channels of $100 \mu \mathrm{m}$ in depth. After the process of removing the remained aluminum, a porous silicon layer on the internal walls of channels was anodized in $10 \% \mathrm{HF}$ electrolyte at $20 \mathrm{~mA} / \mathrm{cm}^{2}$ for $15 \mathrm{~min}$. After that, the silicon wafers were thoroughly rinsed in distilled water and oxidized at $1050^{\circ} \mathrm{C}$ for $1 \mathrm{~h}$. After oxidation process, the silicon nitride formerly patterned as the mask was removed by plasma etching for bonding. Finally glass covers (Corning Pyrex\#7740), in which three holes had been drilled corresponding to the silicon substrate, were anodically bonded to the silicon wafers to form the closed channel by a bonder (Suss, SB6), thus microfluidic devices are fabricated.

\subsection{Online cell lysis and DNA extraction procedure}

The microdevice was mounted onto the stage of a microscope with a CCD camera and a video monitoring system. Blood was introduced through the cell inlet by a peristaltic pump, while 
lysis buffer (namely, load buffer) was pumped through the buffer inlet by another peristaltic pump. The value of the flow velocity was changed from $0.1 \mu \mathrm{L} / \mathrm{min}$ to $25 \mu \mathrm{L} / \mathrm{min}$. When the lysis buffer and blood were blended in the channel during the continuous flow, cells were gradually lyzed online, and then genomic DNA was released and absorbed on the porous silicon matrix. DNA extraction procedure itself consisted of load, wash, and elution steps. In the load step, the released DNA was absorbed onto the porous silicon matrix in the presence of low $\mathrm{pH}(\mathrm{pH}$ 6.7) and high concentration binding salt (4M GuSCN). And then proteins and possible PCR inhibitors were removed by passing $70 \%$ ethanol twice through the microdevice. Finally, DNA was eluted in TE buffer. $5 \mu \mathrm{L}$ TE buffer was introduced in the microdevice for 10 min at $55^{\circ} \mathrm{C}$ and then $20 \mu \mathrm{L}$ TE buffer was continuously passed through the microdevice.

\subsection{Fluorescence detection and PCR amplification}

DNA collected in the elution step was quantified by using SYBR Green I dye in a fluorometer using calibration curve of DNA which were generated using lambda DNA. Then DNA purified from whole blood was amplified by polymerase chain reaction (PCR). The 203-bp -gapd gene of rat's blood was amplified using the following primers: Forward Primer: 5'-AGAAGTACCTGCAACAGG- 3', Reverse Primer: 5'GACGGACACATTGGGGGT- 3'. PCR reactions consisted of $2.5 \mu \mathrm{L}$ standard $10 \times$ PCR buffer, $100 \mu \mathrm{mol}$ dATP, dGTP, dCTP, and dTTP, 2.5 units of Taq polymerase, 50nmol of each primer, $5 \mu \mathrm{L}$ of the initial collected fraction, in a total volume of $25 \mu \mathrm{L}$. These reactions were cycled in under the following conditions: $95^{\circ} \mathrm{C}$ denaturation for $5 \mathrm{~min}, 35$ cycles of $94^{\circ} \mathrm{C}$ for $1 \mathrm{~min}, 68^{\circ} \mathrm{C}$ for $1 \mathrm{~min}, 72^{\circ} \mathrm{C}$ for $1 \mathrm{~min}$, followed by a $10 \mathrm{~min}$ extension at $72^{\circ} \mathrm{C}$. DNA amplification was confirmed by gel electrophoresis.

\section{Results and discussion}

\subsection{Design and simulation of mixing process}

In general, comprehensive computational fluid dynamics (CFD) simulations are conducted before physical models are built and tested since these simulations enable the system parameters to be varied over a wide range of values and permit the simultaneous and instantaneous data collection of various aspects of models. Numerical simulation plays a key role in optimizing designs of microdevices and enables a reliable interpretation of the experimental results. T-type mixing model, sandwich-type mixing model with lined channel and coiled channel were designed and numerical simulated using FLUENT 6.2 software and all the simulations were two-dimensional.

The numerical simulation results are shown in Fig. 2. The mixing performance in sandwichtype mixing model is better than that in T-type one because of the increase of the contact area, and the mixing performance in coiled channel is much better than that in lined channel. Those numerical simulation results mentioned above provide a very clear understanding of the physical phenomena taking place in the two-dimensional microfluidic channels. In order to get a more accurate evaluation of the degree of mixing in the microchannel, a mixing index $(\sigma)$ is used as follows (Erickson \& Li, 2002):

$$
\sigma=\left(1-\frac{\int_{0}^{h}\left|c-c_{\infty}\right| d y}{\int_{0}^{h}\left|c_{0}-c_{\infty}\right| d y}\right) \times 100 \%
$$


where $C$ is the species concentration profile across the width of the microchannel $(h), c \infty$ is the completely mixed state $(=0.5)$ and $C_{0}$ is the completely unmixed state $(=0$ or 1$)$. Note that the confluent streams are completely mixed if $\sigma=100 \%$. In contrast, they are completely unmixed if $\sigma=0 \%$.

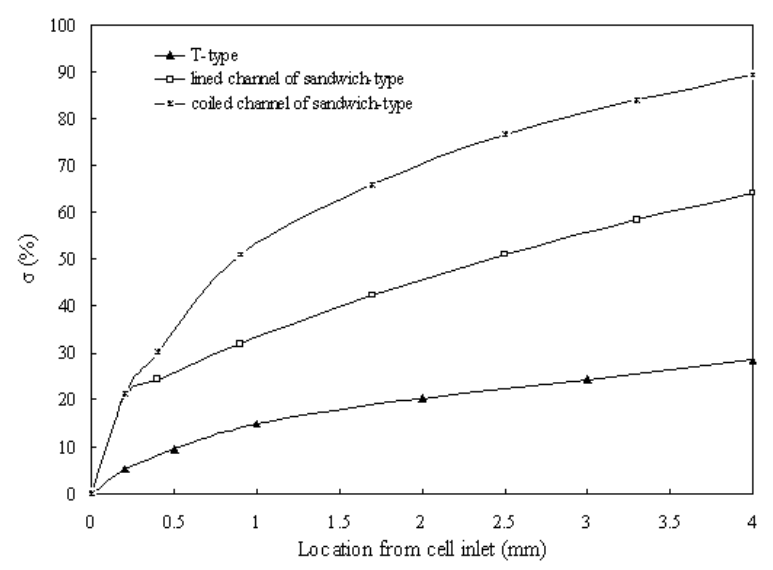

Fig. 3. Numerical evaluations of mixing efficiency index $(\sigma)$ at different mixing models when $\mathrm{v}_{\text {cell }}=0.005 \mathrm{~m} / \mathrm{s}, \mathrm{v}_{\text {buffer }}=0.0025 \mathrm{~m} / \mathrm{s}$

Fig. 3 demonstrates the mixing efficiency of the proposed mixing models: T-type, sandwichtype with lined channel and sandwich-type with coiled channel. The use of coiled channel is effective in enhancing chaotic mixing, in which the mixing efficiency of $89.3 \%$ is obtained at the cross section located $4 \mathrm{~mm}$ from inlet, by folding, stretching and reorienting fluid. Based on discussion above, the coiled channel of sandwich-type mixing model is chosen to construct the physical microdevice.

\subsection{Optimization of cell lysis process}

For cell lysis based on chemical disruption method, there are two steps which are mixing and chemical reaction respectively. In the microdevice, mixing is slow compared with the chemical reaction rate due to the fact that mixing in the microdevice is exclusively caused by diffusion because of laminar flow. The total lysis of cells requires that each cell should be fully exposed to lysis buffer, which is limited by the mixing speed. Thus the cell lysis efficiency is strongly depended on the mixing performance between the cell solution and the lysis buffer. From above results of simulation, a microdevice utilizing sandwich-type mixing model with coiled channel was designed and fabricated. As is shown in Fig. 4, the microdevice consists of a glass cover with two inlets and one outlet and a silicon substrate with an etched coiled channel of $200 \mu \mathrm{m}$ wide, $100 \mu \mathrm{m}$ deep and $20.16 \mathrm{~cm}$ long.

The cell lysis performance is not only influenced by the design of the microchannels but also impacted by the velocity of the two solutions. With the increase of velocity, the time for cell lysis is reduced while the cell lysis efficiency decreases. In order to reduce the time for cell lysis and obtain high cell lysis efficiency, the velocity should be carefully examined. At first, the relationship between the mixing efficiency index and the inlet velocity was simulated using the coiled channel of sandwich-type mixing model. 

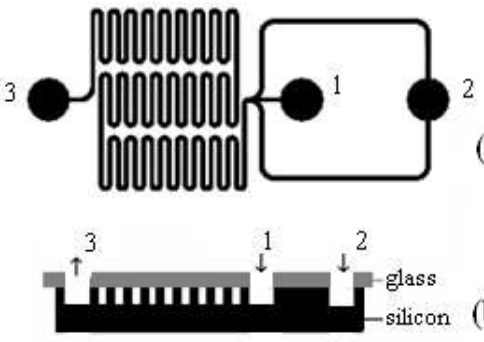

(a)

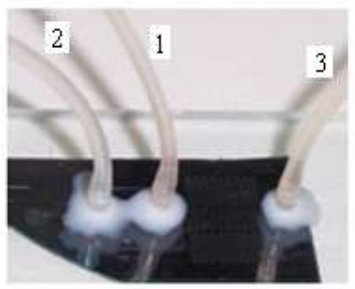

(c)

Fig. 4. Schematic top view (a), cross view (b) and photograph (c) of the microdevice.

(1) Cell inlet; (2) Buffer inlet; (3) Outlet.

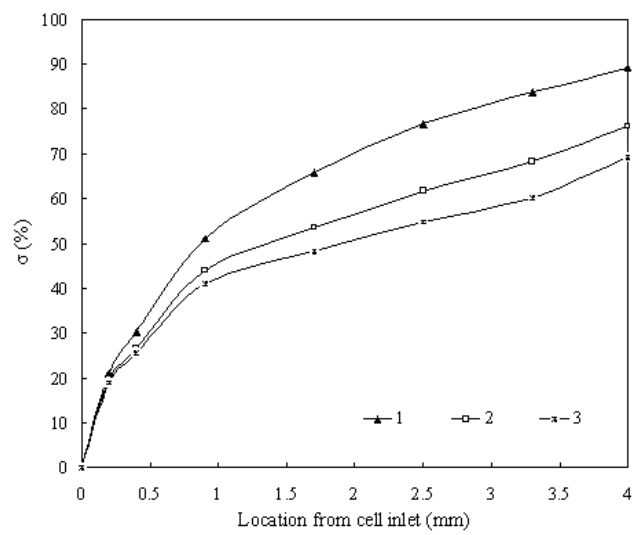

(A)

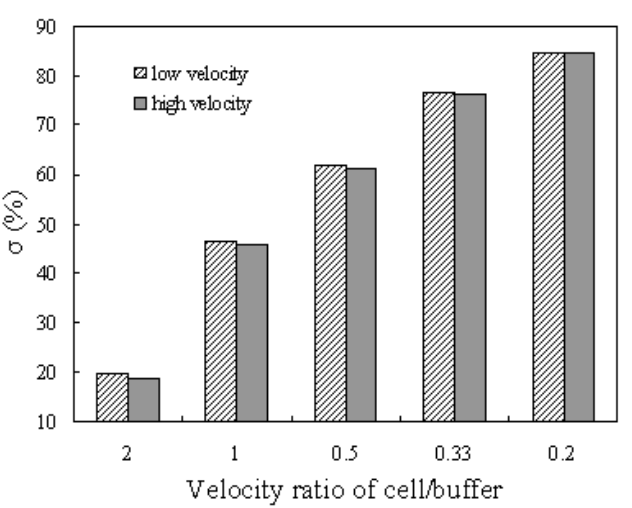

(B)

Fig. 5. Numerical evaluations of mixing efficiency index ( $\sigma)$ of coiled channel of sandwichtype mixing model. (Left) With different inlet velocities: " 1 " $\mathrm{v}_{\text {cell }}=0.005 \mathrm{~m} / \mathrm{s}, \mathrm{v}_{\text {buffer }}=$ $0.0025 \mathrm{~m} / \mathrm{s} ; “{ }^{\prime \prime}$ " $\mathrm{v}_{\text {cell }}=0.02 \mathrm{~m} / \mathrm{s}, \mathrm{v}_{\text {buffer }}=0.01 \mathrm{~m} / \mathrm{s} ; “{ }^{\prime}$ " $\mathrm{v}_{\text {cell }}=0.2 \mathrm{~m} / \mathrm{s}, \mathrm{v}_{\text {buffer }}=0.1 \mathrm{~m} / \mathrm{s}$. (Right) At the location near the inlet with different velocity ratio: "low velocity" $\mathrm{v}_{\text {buffer }}=0.01 \mathrm{~m} / \mathrm{s}$; "high velocity" vbuffer $=0.1 \mathrm{~m} / \mathrm{s}$.

As is shown in Fig. 5A, the mixing efficiency is sharply decreased with the increase of the inlet velocity. This decrease of mixing efficiency can likely be attributed to the insufficient diffusion for the limited diffusion time. For the laminar flowing, the mixing time is proportional to the square of diffusion length so that decreasing diffusion length would reduce the mixing time sharply without deterioration of the mixing efficiency. The diffusion length can be changed by varying the cell and buffer velocity ratio. The lower cell/buffer velocity ratio leads to shorter diffusion length which can enhance mixing efficiency. Moreover at the location near the junction of three streams, the distribution of the laminar flow of the horizontal stream caused by the vertical streams enhances fluid mixing. And this enhancement is much stronger at the lower cell/ buffer velocity ratio. When the cell/buffer velocity ratio is 0.2 , the mixing efficiency index is found to be more than $80 \%$ near the junction, which is insensitive to the value change of the flow velocity, shown in Fig. 5B. 
In order to test the above results of simulation, the experiments of cell lysis were conducted by using the microfluidic device (Fig.4c). The cell sample was whole blood, while the lysis buffer was load buffer, 4M GuSCN in TE buffer with 1\% Triton-X 100, titrated to $\mathrm{pH} 6.7$. Triton X-100 is generic surfactants, with amphoteric chemical properties, which can react with water and can also react with lipid. High concentration guanidine salt is typical bonding salt for solid phase extraction nucleic acid and is also a generic strong denaturant. Moreover guanidine salt can quickly dissolve protein and can destroy the structure of cells. So the mixture of the traditional surfactant and the typical bonding salt was used as the lysis buffer for online cell lysis and DNA extraction.

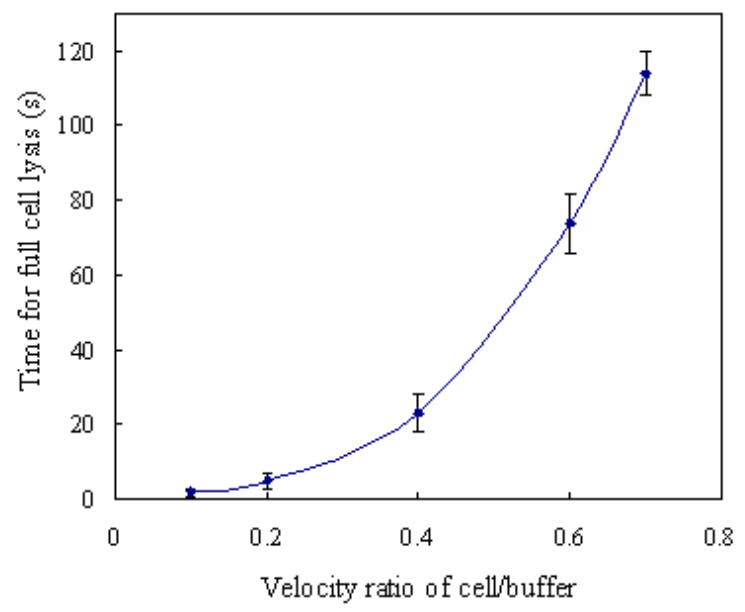

Fig. 6. Experimental evaluations of time for full cell lysis at variation of flow velocity ratio of cell $/$ buffer when vbuffer $=1 \mu \mathrm{L} / \mathrm{min}$.

At first, the effect of flow velocity on the time taken for cell lysis was analyzed when the velocity ratio of cell/buffer was $1: 1$. For the flow velocity of $0.1,0.2,0.4$ and $0.5 \mu \mathrm{L} / \mathrm{min}$, the time taken for complete lysis was tested to be 188s, 188s, 175s and 194s, at the location which was $3.92 \mathrm{~cm}, 7.84 \mathrm{~cm}, 14.56 \mathrm{~cm}$ and $20.16 \mathrm{~cm}$ from the inlet along the channel respectively. Note that the flow velocity of $1 \mu \mathrm{L} / \mathrm{min}$ is equivalent to $0.833 \mathrm{~mm} / \mathrm{s}$ in the microchannel of $200 \mu \mathrm{m}$ wide and $100 \mu \mathrm{m}$ deep. The time taken for completely lysis at different flow rate with the same cell/buffer ratio was approximately the same; however cells could not be fully lyzed in the microdevice at more than $0.5 \mu \mathrm{L} / \mathrm{min}$. Then, the velocity ratio of cell/buffer was varied. As is shown in Fig. 6, the time required for full lysis is sharply reduced from approximate two minutes to several seconds with the decrease of the cell/buffer velocity ratio from 0.7 to 0.1 . The photograph pictures of Fig. 7 show that the width of the cell stream is reduced with the decrease of the cell/buffer velocity ratio and is not affected by specific rate value. These experimental results are found to be consistent with the numerical results. Thus rapid cell lysis can be implemented under the condition of lower cell/buffer velocity ratio and higher specific rate value. In the end the cell velocity of $5 \mu \mathrm{L} / \mathrm{min}$ and the lysis buffer velocity of $15 \sim 25 \mu \mathrm{L} / \mathrm{min}$ were used for rapidly cell lysis. 


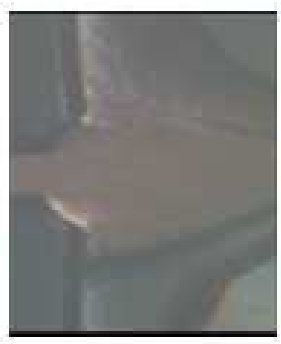

a

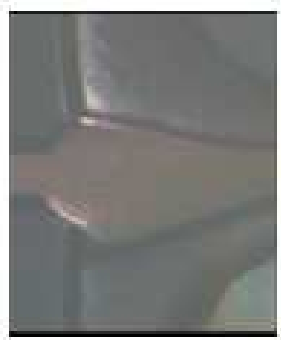

e

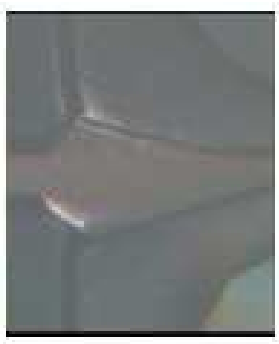

b

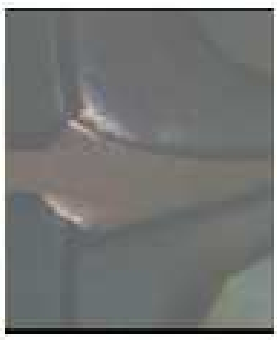

f

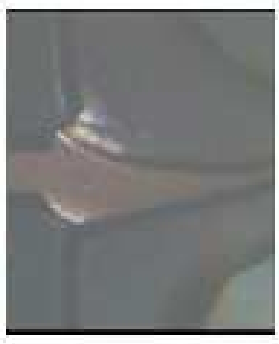

c

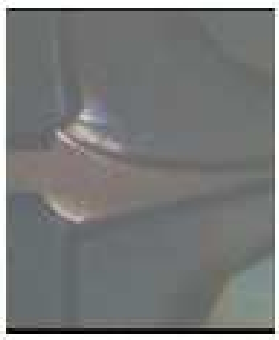

g

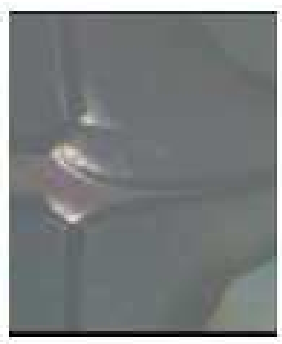

d

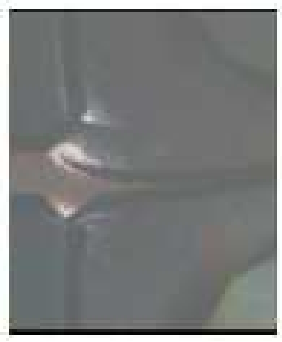

h

Fig. 7. Experimental results for the cell and buffer concentration distributions at location near the inlet with different velocity: " $a$ " $v_{\text {cell }}: v_{\text {buffer }}=2: 1, v_{\text {buffer }}=1 \mu L / \mathrm{min}$; " $b$ " $v_{\text {cell }}: v_{\text {buffer }}$ $=1: 1, \mathrm{v}_{\text {buffer }}=1 \mu \mathrm{L} / \mathrm{min} ;$ " $\mathrm{c}^{\prime \prime} \mathrm{v}_{\text {cell }}: \mathrm{v}_{\text {buffer }}=1: 3, \mathrm{v}_{\text {buffer }}=1 \mu \mathrm{L} / \mathrm{min} ; “$ " $\mathrm{d}^{\prime} \mathrm{v}_{\text {cell }}: \mathrm{v}_{\text {buffer }}=1: 5, \mathrm{v}_{\text {buffer }}=$ $1 \mu \mathrm{L} / \mathrm{min} ;$ " $\mathrm{e}$ " $\mathrm{v}_{\text {cell }}: \mathrm{v}_{\text {buffer }}=2: 1$, $\mathrm{v}_{\text {buffer }}=10 \mu \mathrm{L} / \mathrm{min} ;$ " $\mathrm{f}$ " $\mathrm{v}_{\text {cell }}: \mathrm{v}_{\text {buffer }}=1: 1$, $\mathrm{v}_{\text {buffer }}=10 \mu \mathrm{L} / \mathrm{min}$; “g" $\mathrm{v}_{\text {cell }}: \mathrm{v}_{\text {buffer }}=1: 3$, $\mathrm{v}_{\text {buffer }}=10 \mu \mathrm{L} / \mathrm{min} ; “ \mathrm{~h}^{\prime} \mathrm{v}_{\text {cell }}: \mathrm{v}_{\text {buffer }}=1: 5, \mathrm{v}_{\text {buffer }}=10 \mu \mathrm{L} / \mathrm{min}$.

\subsection{DNA purification using porous silicon matrix}

DNA purification on-microdevice is based on SPE method: firstly adsorption of DNA onto a solid-phase matrix surface and then washing the impurities such as protein and finally elution of the purified DNA. The mechanism of DNA adsorption on a solid-phase matrix surface elucidated by Melzak et al. (Melzak et al., 1996) was that the adsorption of highly charged duplex DNA to negatively charged silica was controlled by three competing effects: weak electrostatic repulsion forces, dehydration and hydrogen bond formation. The surface area of the matrix significantly affects the adsorption of DNA onto the solid-phase matrix surface.

Porous silicon gotten on the surface of the tortuous rectangle channel in the microdevice by electrochemical etching technology can enhance the available surface area (see Fig. 8). The details of the preparation and optimization process for porous silicon were reported in our previous research (Chen et al., 2006; Chen et al., 2007). By using BET nitrogen adsorption experiment, pore size of the porous silicon is in the range of $20 \mathrm{~nm}$ to $30 \mathrm{~nm}$. And the surface area of porous silicon is approximate $400 \mathrm{~m}^{2} / \mathrm{g}$. Note that the volume of microfluidic device with a tortuous channel of $25 \mathrm{~cm}$ long, $100 \mu \mathrm{m}$ deep and $200 \mu \mathrm{m}$ wide is $0.005 \mathrm{~cm}^{3}$. Thus the surface area to volume of microdevice with porous silicon is approximate $300 \mathrm{~m}^{2} / \mathrm{cm}^{3}$ which is thousands of times higher than that of one without porous silicon since it is known that the surface area to volume of the microdevice without porous silicon is approximate $200 \mathrm{~cm}^{2} / \mathrm{cm}^{3}$. 


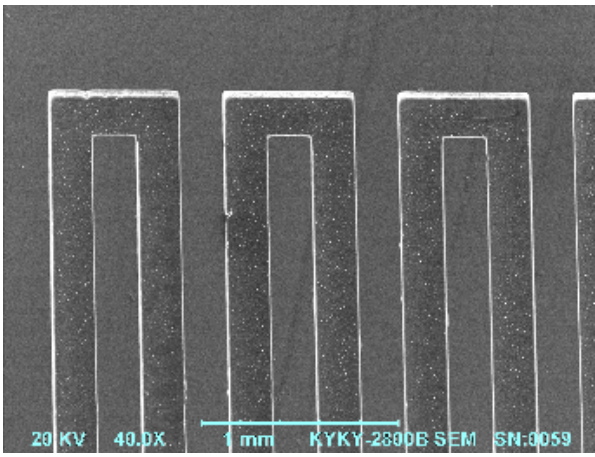

(A)

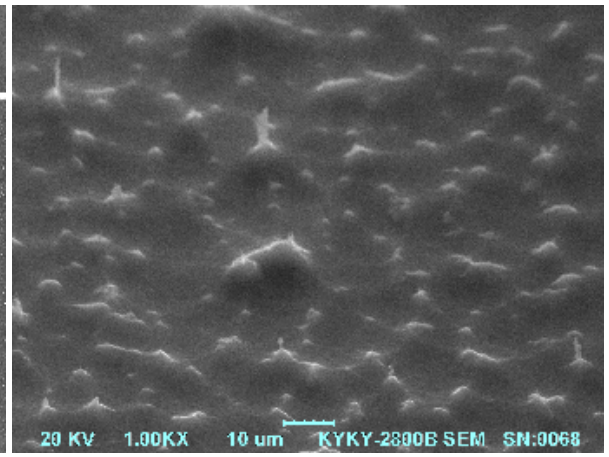

(B)

Fig. 8. SEM of porous silicon on the surface of the channel for DNA purification. (A) $\times 40$; (B) $\times 1000$.

The microdevices with and without porous silicon were used to recover DNA from 200ng prepurified genomic DNA under the same experimental conditions, respectively. The performance of the microdevice with porous silicon is quite well, with an average of $83 \%$ (11.6\% RSD) evaluated from five extractions, which is much higher than that of one without porous silicon with an average of $39.2 \%(8.7 \%$ RSD). It is important to note that 200ng DNA overloads the capacity of the microdevice without porous silicon due to the limitation of surface area. Therefore the binding capacity of the microdevice without porous silicon is approximately $75 \mathrm{ng} / \mathrm{cm}^{2}$ which agrees with the results of Cady et al. (Cady et al., 2003) who found that the binding capacity of nonporous micropillars was approximate $82 \mathrm{ng} / \mathrm{cm}^{2}$. The previous researches proved that the performance of DNA extraction microdevice was determined by the surface area of the matrix and the extracted DNA was found to increase linearly with the surface area (Fan et al., 1999; Kwakye et al., 2006). The binding capacity of porous silicon matrix would increase hundreds or thousands of times, while the extraction efficiency didn't improve so much. The reason could probably be that most of the internal pores and smaller pores might not be used to adsorb DNA, and the DNA adsorbed in these pores might not be easily eluted.

Comparison with the microdevice without the porous silicon layer, the microdevice with the porous layer achieved higher extracting efficiency of DNA without problems of clogging and high backpressure. Moreover this SPE microdevice with porous silicon can be easily integrated with other microdevices, since the porous silicon can be directly generated on the internal walls of channel in the microdevice.

\subsection{Cell lysis and purification of DNA on microdevice}

A microfluidic device capable of real time destroying cells and extracting DNA from the cell lysates during continuous flow was designed and fabricated. As is shown in Fig. 4, the microfluidic device with the size of $2 \mathrm{~cm} \times 1.2 \mathrm{~cm}$ consists of a silicon substrate within an etched coiled channel, and a glass cover with two inlets and one outlet according to the silicon substrate. The two inlets: cell inlet and buffer inlet are designed to introduce blood sample and lysis buffer simultaneously, leading to rapid lysis of blood cells near the location of cell inlet using the sandwich-type mixing model. Porous silicon layer fabricated on the 
surface of the internal wall of the coiled channel is designed to absorb DNA, which can strongly improve the extraction efficiency with the huge surface area. Thus this microfluidic device makes it possible to lyze cells and to purify DNA orderly.

Microfluidic devices with porous silicon matrix were used for lyzing blood cells and purifying genomic DNA, including three steps: load step, washing step, and elution step. In load step, blood cells were damaged, and the genomic DNA was released and adsorbed on the porous silicon matrix. In washing step, impurity such as protein was removed while the genomic DNA was still held on the porous matrix. In elution step, the purified DNA was desorbed from the porous matrix into the elution buffer. The process of online cell lysis and DNA extraction was in details as follows. Firstly, $10 \mu \mathrm{L}$ whole blood was introduced into the channel from the cell inlet, while $50 \mu \mathrm{L}$ lysis buffer was introduced from the buffer inlet. The lysis buffer was load buffer, namely $4 \mathrm{M}$ GuSCN in TE buffer with $1 \%$ Triton-X 100, titrated to $\mathrm{pH}$ 6.7, which included lysis reagent and bonding salt for DNA adsorption. GuSCN and Triton-X 100 were both the chemical reagents for cell lysis, while GuSCN is the bonding salt for DNA extraction. The flow velocity of whole blood sample was $5 \mu \mathrm{L} / \mathrm{min}$, whereas the flow velocity of lysis buffer was $25 \mu \mathrm{L} / \mathrm{min}$. The whole blood sample and the lysis buffer were mixed effectively at the location near the inlet, and blood cells were rapidly lyzed. After cell lysis, genomic DNA in blood cells was released and adsorbed on the porous matrix at the presence of low $\mathrm{pH}(\mathrm{pH}$ 6.7) and high concentration binding salt (4M GuSCN). Secondly, $50 \mu \mathrm{L}$ washing buffer was pumped in the microchannel at $25 \mu \mathrm{L} / \mathrm{min}$ from the buffer inlet, while the cell inlet was closed during washing step. Finally, $10 \mu \mathrm{L}$ of TE buffer was introduced in the microdevices and incubated in the microdevices for $5 \mathrm{~min}$ at $55^{\circ} \mathrm{C}$ and then another $50 \mu \mathrm{L}$ of TE buffer was passed through continuously. As a whole, online cell lysis and genomic DNA purification could be implemented in less than 20min by using this integrated microdevice, while its large-scale counterparts commonly require more than several hours to finish the job.

In order to value the performance of the integrated microdevice, the elution buffer flowing out from the outlet port, in which the purified DNA was desorbed and eluted, was collected and subjected to fluorescence detection using SYBR Green I. From fluorescence detection, average 39.7ng genomic DNA was extracted from $1 \mu \mathrm{L}$ whole blood with $10.5 \%$ RSD by using three microdevices, respectively, at the same conditions. The extracted efficiency of DNA by the integrated microdevices is higher than commercial kit with silica resin which can only extract about 20 30ng DNA per microlitre blood. Moreover, it is only 10 $\mu$ l blood sample needed for the integrated microdevice to extract genomic DNA, while traditional phenol extraction or commercial kit requires several milliliters blood because of centrifugal operation.

The extraction of genomic DNA from a crude biological sample must be PCR-amplifiable. The lyzed cells are a complex mixture of proteins, peptides, lipids, carbohydrates, and other low molecular weight compounds that are known to inhibit DNA amplification by PCR. The genomic DNA extracted from whole blood in two separate experiments, respectively, was submitted for PCR to ensure that no inhibitory compounds were present. Shown in Fig. 9, a 203-bp fragment of -gapd gene is successfully amplified, which is identified by gel electrophoresis separation. This illustrates that the eluted DNA using the microdevice has been purified effectively for subsequent enzymatic reactions. Also shown from Fig. 9, the repeatability of this system is good enough for the downstream analytical steps. 


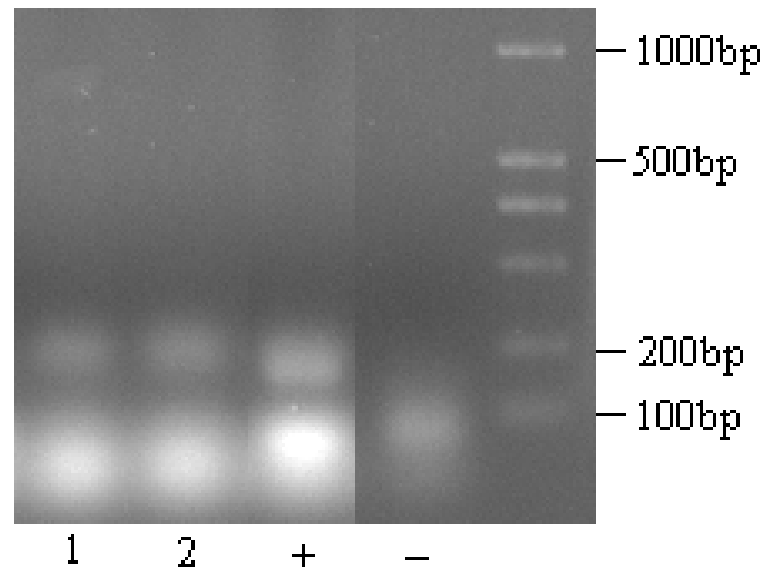

Fig. 9. Gel electrophoresis analysis of PCR products.

\section{Conclusion}

This chapter has demonstrated an integrated microdevice capable of performing online cell lysis and DNA extraction. Firstly micro total analytical systems ( $\mu$ TAS) base on MEMS technology was briefly introduced in Section 1 . Then microdevices both for DNA extraction and cells lyzing were reviewed. The theory of flowing in microdevice was introduced in Section 2. In microdevice channels, the flow is laminar in nature. Then a novel MEMS-based microdevice capable of performing online cell lysis and DNA extraction was reported in Section 3 and 4 . The fabrication procedure of the MEMS-based microdevice was presented in detail, while the experimental of cell lysis and DNA extraction were described respectively. Then the properties of this microdevice were studied by numerical simulation and experimental. According to the results of the simulation, the mixing performance in sandwich-type coiled channels was better than that in the T-type ones. According to the results of the experimental, a high performance of cell lysis was obtained in the sandwichtype microdevice at the optimized conditions of the cell/buffer velocity ratio $<1 / 5$. $83 \%$ DNA was recovered by the porous matrix, strongly contrary to the $39.2 \%$ DNA extracted by the non-porous one. And 39.7ng PCR-amplifiable genomic DNA was obtained from whole blood samples by using an integrated microdevice with sandwich-type coiled channels and porous silicon matrix. In general, the developed integrated microdevice providing a powerful tool for biological sample pre-treatment is shown to exhibit numerous advantages over its large-scale counterparts, including rapidness, much lower blood and reagent consumption, disposability, and portability and so on, which has the potential to integrate into $\mu$ TAS for point-of -care medical diagnose.

\section{Acknowledgement}

The authors greatly acknowledge the financial support from the National Science Foundation of China under Grant number 60701019, 60427001 and 60501020. The authors are grateful to Mr. Feng Shen of Institute of Mechanics, Chinese Academy of Sciences for his assistance. 


\section{References}

Backhouse, C.J.; Gajdal, A.; Pilarski, L.M. \& Crabtree, H.J. (2003). Improved Resolution with Microchip-based Enhanced Field Inversion Electrophoresis, Electrophoresis, Vol.24, pp.1777-1786

Belgrader, P.; Okuzumi, M.; Pourahmadi, F.; Borkholder, D.A. \& Northrup, M.A. (2000). A Microfluidic Cartridge to Prepare Spores for PCR Analysis, Biosens. Bioelectron., Vol.14, pp.849-852.

Bengtsson, M.; Ekström, S.; Marko-Varga, G. \& Laurell, T.; (2002). Improved Performance in Silicon Enzyme Microreactors Obtained by Homogeneous Porous Silicon Carrier Matrix, Talanta, Vol.56, pp.341-53

Bilyalov, R.; Stalmans, L.; Beaucarne, G.; Loo, R.; Caymax, M.; Poortmans, J.; \& Nijs, J. (2001). Porous Silicon as an Intermediate Layer for Thin-Film Solar Cell, Solar Energy Materials and Solar Cells, Vol.65, No.1-4, pp.477-85

Bisi, O.; Ossicini, S. \& Pavesi, L. (2000). Porous Silicon: a Quantum Sponge Structure for Silicon based Optoelectronics, Surface Science Reports, Vol.38, pp.1-126

Björkqvist, M.; Salonen, J.; Paski, J.; \& Laine, E. (2004). Characterization of Thermally Carbonized Porous Silicon Humidity Sensor, Sensors and Actuators A, Vol.112, pp. $244-7$

Breadmore, M.C.; Wolfe, K.A.; Arcibal, I.G.; Leung, W.K.; Dickson, D.; Giordano, B.C.; Power, M.E.; Ferrance, J.P.; Feldman, S.H.; Norris, P.M. \& Landers, J.P. (2003). Microchip-based Purification of DNA from Bilological Samples, Anal. Chem., Vol.75, pp.1880-1886.

Cady, N.C.; Stelick, S. \& Batt, C.A. (2003). Nucleic Acid Purification Using Microfabricated Silicon Structures, Biosens. Bioelectron., Vol.19, pp.59-66.

Carlo, D.D.; Jeong, K.H. \& Lee, L.P. (2003). Reagentless Mechanical Cell Lysis by Nanoscale Barbs in Microchannels for Sample Preparation, Lab chip, Vol.3, pp.287-291.

Chen, X.; Cui, D. F. Liu, C. C. \& Li, H. (2007). Microfabrication and Characterization of Porous Channels for DNA Purification, J. Micromech. Microeng., Vol.17, pp.68-75

Chen, X.; Cui, D. F.; Liu, C. C. \& Cai, H. Y. (2006). Fabrication of Solid Phase Extraction DNA Chips based on Bio-Micro-electron-Mechanical System Technology, Chin. J. Anal. Chem., Vol.34, pp.433-436

Christel, L.A.; Petersen, K.; McMillan, W. \& Northrup, M.A. (1999). Rapid Automated Nucleic Acid Probe Assays Using Silicon Microstructures for Nucleic Acid Concentration, Transactions of the ASME , Vol.121, pp.22-27.

Clicq, D.; Tjerkstra, R. W.; Gardeniers, J. G. E.; van den Berg, A.; Baron, G. V. \& Desmet, G.; (2004). Porous Silicon as a Stationary Phase for Shear-Driven Chromatography, Journal of Chromatography A, Vol.1032, pp.185-91

Copp, M.U.; Luechinger, M.B. \& Manz, A. (1998). Chemical Amplification: Continuous-Flow PCR on a Chip, Science, Vol.280, pp.1046-1048

Erickson, D. \& Li, D. (2002). Influence of Surface Heterogeneity on Electrokenetically Driven Microfluidic Mixing, Langmuir, Vol.18, pp.1883-1892.

Fan, Z.H.; Mangru, S;. Granzow, R.; Heaney, P.; Ho, W.; Dong, Q. \& Kumar, R. (1999). Dynamic DNA Hybridization on a Chip Using Paramagnetic Beads, Anal. Chem., Vol.71, pp.4851-4859 
Gao, J.; Yin, X.F. \& Fang, Z.L. (2004). Integration of Single Cell Injection, Cell Lysis, Separation and Detection of Intracellular Constituents on a Microfluidic Chip, Lab chip, Vol. 4, pp.47-52.

Gravesen, P.; Branebjerg, J. \& Jensen, O.S. Microfluidics-a Review, (1993). J. Micromech. Microeng., Vol.3, pp.168-182.

Harrison, D.J.; Fluri, K.; Seiler, K.; Fan, Z.; Effenhauser, C.S. \& Manz, A. (1993). Micromaching a Miniaturized Capillary Electrophoresis-based Chemical Analysis System on a Chip, Science, Vol.261, pp.895-897

Kwakye, S.; Goral, V.N. \& Baeumner, A.J. (2006). Electrochemical Microfluidic Biosensor for Nucleic Acid Detection with Integrated Minipotentiostat, Biosens. Bioelectron., Vol.21, pp.2217-2223

LaMontagne1, M.G.; Jr., F.C.M.; Holden, P.A. \& Reddy, C.A. (2002). Evaluation of Extraction and Purification Methods for Obtaining PCR-Amplifiable DNA from Compost for Microbial Community Analysis, J. Microbiol. Meth., Vol.49, pp.255-264.

Lee, S.W. \& Tai, Y.C. (1999). A Micro Cell Lysis Device, Sens. Actuat. A, Vol.73, pp.74-79.

Li, P.C.H.\& Jed Harrison, D. (1997). Transport, Manipulation, and Reaction of Biological Cells On-Chip Using Electrokinetic Effects, Anal. Chem., Vol.69, pp.1564-1568.

Liu, D.Y.; Shi, M.; Huang, H.Q.; Long, Z.C.; Zhou, X.M; Qin, J.H. \& Lin, B.C. (2006). Isotachophoresis Preconcentration Integrated Microfluidic Chip for Highly Sensitive Genotyping of the Hepatitis B Virus, J. Chromatogr. B, Vol.844, pp.32-38

Massera, E.; Nasti, I.; Quercia, L.; Rea, I.; \& Di Francia, G. (2004). Improvement of Stability and Recovery Time in Porous-Silicon-based $\mathrm{NO}_{2}$, sensor Sensors and Actuators B, Vol.102, pp.195-7

Melander, C.; Bengtsson, M.; Schagerlöf, H.; Tjerneld, F.; Laurell, T. \& Gorton, L. (2005). Investigation of Micro-Immobilised Enzyme Reactors Containing Endoglucanases for Efficient Hydrolysis of Cellodextrins and Cellulose Derivatives, Analytica Chimica Acta, Vol. 550, pp.182-90

Melzak, K.A.; Sherwood, C.S.; Turner, R.B. \& Haynes, C.A. (1996). Driving Forces for DNA Adsorption to Silica in Perchlorate Solutions, J. Colloid Interf. Sci., Vol.181, pp.635644.

Northrup, M.A.; Ching, M.T.; White, R.M. \& Watson, R.T. (1993). DNA Amplification with a Microfabricated Reaction Chamber,Transducer, pp.924-926

Panaro, N.J.; Lou, X.J.; Fortina, P.; Kricka, L.J. \& Wilding, P. (2005). Micropillar Array Chip for Integrated White Blood Cell Isolation and PCR, Biomolecular Engineering, Vol.21, pp.157-162

Park, J. Y. \& Lee, J. H. (2003). Characterization of $10 \mu \mathrm{m}$ Thick Porous Silicon Dioxide Obtained by Complex Oxidation Process for RF Application, Materials Chemistry and Physics, Vol.82, pp.134-9

Schilling, E.A.; Kamholz, A.E. \& Yager, P. (2002). Cell Lysis and Protein Extraction in a Microfluidic Device with Detection by a Fluorogenic Enzyme Assay, Anal. Chem., Vol.74, pp.1798-1804.

Schmuki, P.; Schlierf, U.; Herrmann, T. \& Champion, G. (2003) Pore Initiation and Growth on n-InP(100), Electrochimica Acta, Vol.48, pp.1301-8

Sethu, P.; Anahtar, M.; Moldawer, L. L.; Tompkins, R. G. \& Toner, M. (2004). Continuous Flow Microfluidic Device for Rapid Erythrecyte Lysis, Anal. Chem., Vol.76, pp.62476253. 
Steinhauer, C.; Ressine, A.; Marko-Varga, G.; Laurell, T.; Borrebaeck, C. A. K. \& Wingren, C. (2005). Biocompatibility of Surfaces for Antibody Microarrays: Design of Macroporous Silicon Substrates, Analytical Biochemistry, Vol.341, pp.204-13

Taylor, M.T.; Belgrader, P.; Furman, B.J.; Pourahmadi, F.; Kovacs, G.T.A. \& Northrup, M.A. (2001). Lysing Bacterial Spores by Sonication through a Flexible Interface in a Microfluidic System, Anal. Chem., Vol.73, pp.492-496.

Tian, H;. Hühmer, A.F.R. \& Landers, J.P. (2000). Evaluation of Silicon Resins for Direct and Efficient Extraction of DNA from Complex Biological Matrices in a Miniaturized Format, Anal. Biochem., Vol.283, pp.175-191.

Waters, L.C.; Jacobson, S.C.; Kroutchinina, N.; Khandurina, J.; Foote, R. S. \& Ramsey, J.M. (1998). Microchip Device for Cell Lysis, Multiplex PCR Amplification, and Electrophoretic Sizing, Anal. Chem., Vol.70, pp.158-162.

Wilson, M.S. \& Nie, W. (2006). Multiplex Measurement of Seven Tumor Markers Using an Electrochemical Protein Chip, Anal. Chem., Vol.78, pp.6476-6483

Wolfe, K.A.; Breadmore, M.C.; Ferrance, J.P.; Power, M.E.; Conroy, J.F.; Norris, P.M. \& Landers, J.P. (2002). Toward a Microchip-based Solid-Phase Extraction Method for Isolation of Nucleic Acids, Electrophoresis, Vol.23, pp.727-733.

Yang, T.; Jung, S.; Mao, H. \& Cremer, P.S. (2001). Fabrication of Phospholipid BilayerCoated Microchannels for on-Chip Immunoassays, Anal. Chem., Vol.73, pp.165-169 


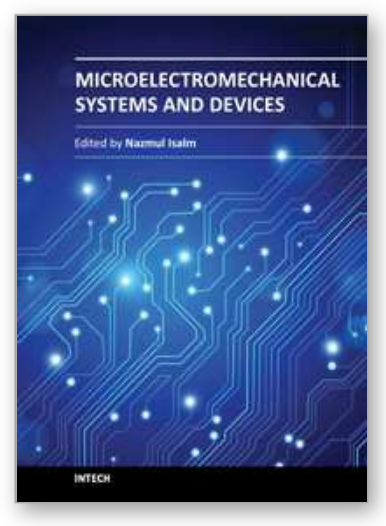

\author{
Microelectromechanical Systems and Devices \\ Edited by Dr Nazmul Islam
}

ISBN 978-953-51-0306-6

Hard cover, 480 pages

Publisher InTech

Published online 28, March, 2012

Published in print edition March, 2012

The advances of microelectromechanical systems (MEMS) and devices have been instrumental in the demonstration of new devices and applications, and even in the creation of new fields of research and development: bioMEMS, actuators, microfluidic devices, RF and optical MEMS. Experience indicates a need for MEMS book covering these materials as well as the most important process steps in bulk micro-machining and modeling. We are very pleased to present this book that contains 18 chapters, written by the experts in the field of MEMS. These chapters are groups into four broad sections of BioMEMS Devices, MEMS characterization and micromachining, RF and Optical MEMS, and MEMS based Actuators. The book starts with the emerging field of bioMEMS, including MEMS coil for retinal prostheses, DNA extraction by micro/biofluidics devices and acoustic biosensors. MEMS characterization, micromachining, macromodels, RF and Optical MEMS switches are discussed in next sections. The book concludes with the emphasis on MEMS based actuators.

\title{
How to reference
}

In order to correctly reference this scholarly work, feel free to copy and paste the following:

Xing Chen, Dafu Cui, Haoyuan Cai, Hui Li, Jianhai Sun and Lulu Zhang (2012). MEMS-Based Microdevice for Cell Lysis and DNA Extraction, Microelectromechanical Systems and Devices, Dr Nazmul Islam (Ed.), ISBN: 978-953-51-0306-6, InTech, Available from: http://www.intechopen.com/books/microelectromechanicalsystems-and-devices/mems-based-microdevice-for-cell-lysis-and-dna-extraction

\section{INTECH}

open science | open minds

\section{InTech Europe}

University Campus STeP Ri

Slavka Krautzeka 83/A

51000 Rijeka, Croatia

Phone: +385 (51) 770447

Fax: +385 (51) 686166

www.intechopen.com

\section{InTech China}

Unit 405, Office Block, Hotel Equatorial Shanghai

No.65, Yan An Road (West), Shanghai, 200040, China

中国上海市延安西路65号上海国际贵都大饭店办公楼 405 单元

Phone: +86-21-62489820

Fax: $+86-21-62489821$ 
(C) 2012 The Author(s). Licensee IntechOpen. This is an open access article distributed under the terms of the Creative Commons Attribution 3.0 License, which permits unrestricted use, distribution, and reproduction in any medium, provided the original work is properly cited. 